Marquette University

e-Publications@Marquette

Biological Sciences Faculty Research and

Publications

Biological Sciences, Department of

$12-2007$

\title{
Cold Responsive EARLI1 Type HyPRPs Improve Freezing Survival of Yeast Cells and Form Higher Order Complexes in Plants
}

\author{
Yi Zhang \\ Medical College of Wisconsin \\ Michael Schläppi \\ Marquette University, michael.schlappi@marquette.edu
}

Follow this and additional works at: https://epublications.marquette.edu/bio_fac

Part of the Biology Commons

\section{Recommended Citation}

Zhang, Yi and Schläppi, Michael, "Cold Responsive EARLI1 Type HyPRPs Improve Freezing Survival of Yeast Cells and Form Higher Order Complexes in Plants" (2007). Biological Sciences Faculty Research and Publications. 55.

https://epublications.marquette.edu/bio_fac/55 


\title{
Cold Responsive EARLI1 type HyPRPs Improve Freezing Survival of Yeast Cells and Form Higher Order Complexes in Plants
}

\author{
Yi Zhang \\ Department of Biological Sciences, Marquette University, \\ Milwaukee, WI \\ Michael Schläppi \\ Department of Biological Sciences, Marquette University, \\ Milwaukee, WI
}

\begin{abstract}
Plants have large families of proteins sharing a conserved eightcysteine-motif ( $8 \mathrm{CM}$ ) domain. The biological functions of these proteins are largely unknown. EARLI1 is a cold responsive Arabidopsis gene that encodes a hybrid proline-rich protein (HyPRP) with a three-domain architecture: a putative signal peptide at the $\mathrm{N}$-terminus, a proline-rich domain (PRD) in the middle, and an $8 \mathrm{CM}$ domain at the $\mathrm{C}$-terminus. We report here that yeast cells expressing different EARLI1 genes had significantly higher rates of freezing survival than empty-vector transformed controls. Arabidopsis plants with knocked down EARLI1 genes had an increased tendency for freezinginduced cellular damage. EARLI1-GFP Fluorescence in transgenic plants and
\end{abstract}


NOT THE PUBLISHED VERSION; this is the author's final, peer-reviewed manuscript. The published version may be accessed by following the link in the citation at the bottom of the page.

immunoblot analyses using protoplasts suggested cell wall localization for EARLI1 proteins. Immunoblot analyses showed that EARLI1 proteins form higher order complexes in plants, and that the PRD is a soluble and the $8 \mathrm{CM}$ an insoluble protein domain. We propose that EARLI1 proteins have a bimodular architecture in which the PRD may interact with the cell wall and the $8 \mathrm{CM}$ domain with the plasma membrane to protect the cells during freezing stress.

\section{Abbreviations}

8CM Eight-cysteine-motif

LTP Lipid transfer protein

CaMV Cauliflower mosaic virus $\beta$-ME $\beta$-Mercaptoethanol

Col Columbia ecotype of

Arabidopsis

EL Electrolyte leakage

PRD Proline-rich domain

PRP Proline-rich protein

EXT Extensin

RNAi RNA interference

HyPRP Hybrid proline-rich protein

\section{Introduction}

As a result of adaptation, plants evolved various strategies to deal with adverse conditions, such as harsh temperatures, dehydration or pathogen attacks (Reeves and Coupland 2000; Whitham and Wang 2004; Zhang et al. 2006). The first place of encounter of all these challenges is the cell wall and the adjacent cell membrane, both of which need to be prepared for stress adaptation. In agreement with this notion it was previously shown that dramatic molecular and cellular rearrangements occur in response to low temperature stress or pathogen attack. In the case of cold stress, the cell membrane undergoes a series of changes in both lipid and protein composition such that the rigidity of the plasma membrane is elevated (Uemura et al. 2006). Changes in cell wall structures were also observed during plant cell cold acclimation (Weiser et al. 1990; Yamada et al. 2002; Wei et al. 2006). In the pathogen defense scenario, the cell wall becomes tougher because of an increased deposition and cross-linking of insoluble cell wall proteins such as extensin (Showalter 1993), leading to a more impenetrable barrier against pathogens. With the common strategy of strengthening the cellular barriers, it is conceivable that plants have evolved a group of proteins that are structurally suitable to interact with both the cell wall and cell

Planta, Vol. 227, No. 1 (December 2007): pg. 233-243. DOI. This article is (C) Springer and permission has been granted for this version to appear in e-Publications@Marquette. Springer does not grant permission for this article to be further copied/distributed or hosted elsewhere without the express permission from Springer. 
membrane to better fulfill the task of cell protection. The EARLI1 gene family in Arabidopsis seems to fit this profile. EARLI1 expression is regulated by multiple environmental cues, including cold and light (Wilkosz and Schläppi 2000; Bubier and Schläppi 2004). The predicted EARLI1 polypeptide starts with a putative signal sequence (Fig. 1), which would direct the protein into the secretory pathway resulting in a cell peripheral localization of the protein. Cleavage of the signal peptide would generate a $14.7 \mathrm{kDa}$ EARLI1 protein with two domains. The $\mathrm{N}$-terminal portion consists of a hydrophilic proline-rich domain (PRD), sharing high similarity with polypeptides found in the cell wall, such as the proline-rich proteins (PRPs) and extensins. The C-terminus of EARLI1 contains a hydrophobic eight-cysteine-motif (8CM) that may associate with the plasma membrane. For DEA1, a tomato protein with $50-65 \%$ identity to the EARLI1 protein family, presumed membrane association was confirmed by localization studies (Weyman et al. 2006a). EARLI1 type proteins may thus play a dual role at the cell periphery.

About 500 proteins known from different plant species have been classified into the 8CM superfamily, because they contain eight cysteine residues at conserved positions (Josè-Estanyol et al. 2004). Of $1058 \mathrm{CM}$ proteins in Arabidopsis, 23 proteins including EARLI1 were grouped together as hybrid proline-rich proteins (HyPRP), because after the signal sequence they have a PRD in front of a typically hydrophobic 8CM domain. This PRD-8CM bimodular domain architecture of hybrid proline-rich proteins is also a hallmark of seven EARLI1 paralogs, six of which are clustered with EARLI1 in a tandem array at the same chromosomal locus. As shown in Fig. 1, four members (including EARLI1) of this group are closely related and form a separate branch in the HyPRP phylogenetic tree (Josè-Estanyol et al. 2004). Interestingly, each of the four members, At4g12470, At4g12480 (EARLI1), At4g12490, and At4g12500, is cold responsive (Vogel et al. 2005). Biochemical and genetic approaches were used here to further investigate the potential role EARLI1 and perhaps its closely related paralogs play in plant cell protection.

Planta, Vol. 227, No. 1 (December 2007): pg. 233-243. DOI. This article is (C) Springer and permission has been granted for this version to appear in e-Publications@Marquette. Springer does not grant permission for this article to be further copied/distributed or hosted elsewhere without the express permission from Springer. 
NOT THE PUBLISHED VERSION; this is the author's final, peer-reviewed manuscript. The published version may be accessed by following the link in the citation at the bottom of the page.

\section{Materials and Methods}

\section{Plant materials and culture conditions}

Arabidopsis thaliana L. ecotype Columbia (Col-0) plants and the late-Xowering Col-FRI-Sf2 line (Lee and Amasino 1995) used as wildtype control plants were kindly provided by Dr. Richard Amasino (University of Wisconsin, Madison, WI, USA). An Arabidopsis line overexpressing EARLI1 in the Col-0 background was described previously (Bubier and Schläppi 2004). An EARLI1 knockdown line, in which the expression of EARLI1 and its three closest paralogs (At4g12470, At4g12490, At4g12500) were knocked down by RNA interference, was created in the Col-FRI-Sf2 background. Surfacesterilized seeds were initially grown on $0.8 \%$ agar-solidified medium (Difco, Detroit, MI, USA) containing half-strength MS (Murashige and Skoog 1962) salts (Gibco BRL, Grand Island, NY, USA) for 10-14 days in a short-day photoperiod ( $8 \mathrm{~h}$ light/16h dark cycles) with approximately $65 \mu \mathrm{mol} \mathrm{m} \mathrm{m}^{-2} \mathrm{~s}^{-1}$ photon flux and $25^{\circ} \mathrm{C}$ day $/ 22^{\circ} \mathrm{C}$ night temperatures. The largest plantlets were then transferred to artificial soil (1:1 mix of vermiculite:perlite) into 2 -inch pots (four plants/pot; 32 pots/flat) and grown under cool fluorescent light with a $16-\mathrm{h}$ light/8-h dark longday-photoperiod, $20 \pm 1^{\circ} \mathrm{C}$ day/night temperature, and about $60-70 \%$ relative humidity. Flats were watered three times per week with 0.1 g/l 15-16-17 Peters fertilizer (Grace Sierra, Milpitas, CA, USA). For cold acclimation treatment, Petri dishes or flats with plants in soil were transferred to $4^{\circ} \mathrm{C}$ and short-day photoperiod for normally 3-7 days.

\section{EARLI1 RNAi knockdown constructs}

For the RNAi knockdown construct, a 132 bp region within the conserved $8 \mathrm{CM}$ domain of EARLI1 was amplified from a CDNA template using PCR primers 5'-TGCTCTAGAGCATTTGGTTGACCTCGACG-3' (XbaI site underlined) and 5'-CCATCGATGGGCCAGACGGAACCTTTC-3' (ClaI site underlined) to create the antisense copy of EARLI1 for the hairpin of the RNAi construct, and PCR primers 5'CCGCTCGAGCGGTTTGGTTGA CCTCGACG-3' (XhoI site underlined) and 5'-CGGGGTACCCCGGCCAGA CGGAACCTTTC-3' (KpnI site underlined) to create the sense copy of EARLI1 for the hairpin. PCR products were cloned into pGEM-T

Planta, Vol. 227, No. 1 (December 2007): pg. 233-243. DOI. This article is @ Springer and permission has been granted for this version to appear in e-Publications@Marquette. Springer does not grant permission for this article to be further copied/distributed or hosted elsewhere without the express permission from Springer. 
(Promega, Madison, WI, USA), either double-digested with $X b a I$ and $\mathrm{ClaI}$ or XhoI and $\mathrm{KpnI}$, and ligated into either XbaI and ClaI or XhoI and $K p n I$ double-digested pHANNIBAL (Wesley et al. 2001). Resulting constructs were sequenced (MGW-Biotech Inc., High Point, NC, USA), digested with NotI and ligated into the NotI digested binary vector PART27 (Gleave 1992), cloned in Escherichia coli, and introduced into Agrobacterium tumefaciens strain ABI for plant transformation.

\section{Isolation of EARLI1-LIKE genes}

EARLI1 paralogs, At4g12470, At4g12490 and At4g12500, were amplified from Col-0 genomic DNA using PCR primers 5'CTAGGATCCTATAAATACCAA-3' and 5'-ATC GAATTCATAATGGATATT-3' for At4g12470; PCR primers 5'-TCATATGATCGGATCCTTCTA-3' and 5'TATGTGTAATTGAATTCCCTC-3' for At4g12490; and PCR primers 5'CTCAATCAAGGATCCTTAAAA-3' and 5'-TAATGAATTCAAAGAGAACAC-3' for At4g12500 (BamHI and EcoRI sites, respectively, underlined). PCR products were ligated into PGEM-T and sequenced.

\section{RNA gel blot analysis and probes}

Total RNA isolation and RNA gel blot analysis was done as described previously (Bubier and Schläppi 2004). Normally 20-25 $\mu \mathrm{g}$ of total RNA was used for RNA gel blot analysis. At4g12470, EARLI1, At4g12490, At4g12500, and 18S rDNA probes were made as described previously (Bubier and Schläppi 2004). The degree of crosshybridization between probes for EARLI1 and its three paralogs was analyzed by hybridizing each probe to PCR amplified DNA of all four family members. No cross-hybridization was observed, except between At4g12490 and At4g12500.

\section{Electrolyte leakage (EL) assays}

EL assays were performed as described (Warren et al. 1996) with slight modifications. Three to four pieces of leaves from 3-weekold plants grown in artificial soil and cold acclimated for 3 days at $4^{\circ} \mathrm{C}$ were randomly chosen from a pool of plants with the same genetic background, washed with ice-cold $\mathrm{dd}_{2} \mathrm{O}$, and put into glass tubes on ice containing $50 \mu \mathrm{l}$ of ice-cold $\mathrm{ddH}_{2} \mathrm{O}$. Triplicates of tubes were used

Planta, Vol. 227, No. 1 (December 2007): pg. 233-243. DOI. This article is C Springer and permission has been granted for this version to appear in e-Publications@Marquette. Springer does not grant permission for this article to be further copied/distributed or hosted elsewhere without the express permission from Springer. 
for each temperature point. Glass tubes were then incubated in a programmable cooling bath preset at $-1^{\circ} \mathrm{C}$ for $15 \mathrm{~min}$, after which ice chips were added to induce ice nucleation. Tubes were incubated at $-1^{\circ} \mathrm{C}$ for one more hour, after which the bath temperature was gradually ramped down to $-12^{\circ} \mathrm{C}$ at a rate of $2^{\circ} \mathrm{C} / \mathrm{h}$. Samples were removed at different temperature points and thawed overnight at $4^{\circ} \mathrm{C}$. Two milliliter of $\mathrm{ddH}_{2} \mathrm{O}$ was then added and tubes were shaken at room temperature for $2 \mathrm{~h}$. Conductivity of the liquid in each tube was measured with a conductivity meter. To induce $100 \%$ leakage, samples were boiled for $15 \mathrm{~min}$ and shaken for another hour before second conductivity measurements. The percent freezing-induced electrolyte leakage was calculated by dividing the First reading by the second (total leakage) minus the leakage of controls kept at $4^{\circ} \mathrm{C}$. Results of three experiments were averaged and means were compared by Student's $t$ test analysis.

\section{Yeast strain, expression vector, and growth media}

Saccharomyces cerevisiae W303-1A MATa (leu2-3,112 trp1-1 can1-100 ura3-1 ade2-1 his3-11,15; Veal et al. 2003) cells were used as host strain. Plasmid pESC-URA (Stratagene, La Jolla, CA, USA) was used to express myctagged EARLI1 (At4g12480; pESC-480) or EARLI1-LIKE genes At4g12470 (pESC-470), At4g12490 (pESC-490), or At4g12500 (pESC-500) under the regulation of the GAL1 promoter. Yeast cells were grown from single colony in SC-URA culture [1.45g/l yeast nitrogen base without amino acid or ammonium sulfate (Sigma); $5 \mathrm{~g} / \mathrm{l}$ ammonium sulfate (Sigma) ; $2 \mathrm{~g} / \mathrm{l}$ yeast dropout mix (-URA)] supplemented with $2 \%$ sucrose. For GAL1 induction, galactose was added to a final concentration of $2 \%$.

\section{Yeast freezing assay}

Yeast freezing assays were performed as described (Zhang et al. 2000; Weyman et al. 2006b) with slight modifications. S. cerevisiae cells harboring either the empty vector pESC-URA or one of the recombinant plasmids pESC-470, pESC-480, pESC-490, or pESC-500 were grown overnight from a single colony in non-inducing $2 \%$ sucrose SC-URA medium. Cell cultures were diluted to an $\mathrm{OD}_{600}$ of 0.1 with $2 \%$ sucrose SC-URA medium supplemented with $2 \%$ galactose for GAL1

Planta, Vol. 227, No. 1 (December 2007): pg. 233-243. DOI. This article is (C) Springer and permission has been granted for this version to appear in e-Publications@Marquette. Springer does not grant permission for this article to be further copied/distributed or hosted elsewhere without the express permission from Springer. 
promoter induction and grown for $24 \mathrm{~h}$. Cells were diluted again in the same medium to an $\mathrm{OD}_{600}$ of 0.2 and grown to an $\mathrm{OD}_{600}$ of about 0.7 . For each culture, similar amounts of cells were collected by a brief centrifugation and resuspended in $1 \mathrm{ml}$ of sterile water. Four 0.1-ml aliquots of cell cultures were serially diluted and spread on SC-URA agar plates. Another four $0.1-\mathrm{ml}$ aliquots were frozen at $-20^{\circ} \mathrm{C}$ in a precooled metal block. After $24 \mathrm{~h}$, the frozen aliquots were thawed, serially diluted, and plated on SC-URA. Colonies on each plate were counted and averaged. Survival frequencies for each yeast line was calculated as the ratio of the number of freezing survivors divided by the number of cells before freezing treatment. For each experiment an empty vector control was included. Survival frequencies of three to six experiments were combined and means were compared by Student's $t$ test analysis.

\section{Protein expression and antibody production}

EARLI1 open reading frame lacking the putative signal peptide was amplified using PCR primers 5'-CGC GGATCCACAGATTGTGGTTGC3' (BamHI site underlined) and 5'-CGCCTCGAGTCAAGCACATTGGAA-3' (XhoI underlined), ligated into pGEM-T, sequenced, and subcloned into the expression vector pET28 (Novagen, San Diego, CA, USA) to produce an $\mathrm{N}$-terminally tagged $6 x \mathrm{His}-E A R L I 1$ recombinant polypeptide in $E$. coli. DNA sequences encoding the PRD and the 8CM domains of EARLI1 were amplified using PCR primers 5'-CGC GGATCCACAGATTGTGGTTGC-3' (BamHI site underlined) and 5'CGCCTCGAGTCAGTTTCCAGATGA GCC-3' (XhoI site underlined), and PCR primers 5'-CGCGGATCCATGGGCTCATCTGGAAAC-3' (BamHI site underlined) and 5'-CGCCTCGAGTCAAGCACATT GGAA-3' (XhoI site underlined), respectively, and were individually ligated into pET28 to produce $\mathrm{N}$-terminally tagged $6 \times$ His-PRD and $6 \times$ His-8CM recombinant polypeptides. E. coli cells were induced with $1 \mathrm{mM}$ isopropyl-beta-Dthiogalactopyranoside (IPTG; Sigma) for about $3 \mathrm{~h}$. Recombinant protein was isolated from inclusion bodies as recommended by the manufacturers (Novagen) and separated on a $16 \%$ SDSpolyacrylamide gel and stained with Coomassie Blue. The area in the gel containing $6 \times$ His-EARLI1 was cut out and gel pieces were sent to Spring Valley Laboratories (Woodbine, MD, USA) for antibody production. Rabbits were bled twice, 31 and 52 days after the primary

Planta, Vol. 227, No. 1 (December 2007): pg. 233-243. DOI. This article is @ Springer and permission has been granted for this version to appear in e-Publications@Marquette. Springer does not grant permission for this article to be further copied/distributed or hosted elsewhere without the express permission from Springer. 
immune-inducing injection. Serum samples were also collected before immune induction, and were used as the pre-immune controls throughout the experiments.

\section{Immunodetection of EARLI1 proteins expressed in S. cerevisiae}

Yeast cells transformed with either pESC-470, pESC-480, pESC490 , or pESC-500 were cultured in $2 \%$ sucrose SCURA medium to an $\mathrm{OD}_{600}$ of 0.2 . Cultures were then supplemented with $2 \%$ galactose and grown to an $\mathrm{OD}_{600}$ of 0.7 . To isolate total proteins, cold $\mathrm{ddH}_{2} \mathrm{O}$-washed yeast cells were broken in a mixture of $10 \%$ TCA and glass beads by vortexing eight times, $15 \mathrm{~s}$ each, with $15 \mathrm{~s}$ intervals on ice. Precipitated proteins were collected by centrifugation, washed with acetone, and resuspended in SDS-PAGE loading buffer. The amounts of protein loaded were normalized with the yeast cell densities. After separation by $16 \%$ SDSPAGE, proteins were electrotransferred to $0.45-\mu \mathrm{m}$ nitrocellulose membranes (Schleicher and Schuell, Keene, $\mathrm{NH}$, USA). Membranes were blocked in $5 \%(\mathrm{w} / \mathrm{v})$ skim milk $1 \times$ TBS solution, followed by incubation for $2 \mathrm{~h}$ at room temperature with mouse anti-myc antibodies (1:5,000 dilution). Goat anti-mouse IgG peroxidase conjugate (BioRad) at a 1:5,000 dilution was used to visualize antibody-bound myc portions of the recombinant proteins on Film. To determine EARLI1 antibody specificity, anti-EARLI1 antiserum (1:500 dilution) and goat anti-rabbit IgG peroxidase conjugate (Sigma) at a 1:5,000 dilution were used to visualize EARLI1 or crossreacting EARLI1-LIKE proteins on film.

\section{Immunodetection of EARLI1 proteins expressed in E. coli and Arabidopsis}

Solubility of proteins expressed in E. coli was determined by separating total protein into soluble and insoluble matters as recommended by the manufacturers (Novagen). Equal amounts of protein were separated by $16 \%$ SDS-PAGE and electrotransferred to $0.45-\mu \mathrm{m}$ nitrocellulose membranes. Membranes were blocked in $5 \%$ (w/v) skim milk $1 \times$ TBS solution, followed by incubation for $2 \mathrm{~h}$ at room temperature with mouse anti-His antibodies (1:5,000 dilution).

Planta, Vol. 227, No. 1 (December 2007): pg. 233-243. DOI. This article is @ Springer and permission has been granted for this version to appear in e-Publications@Marquette. Springer does not grant permission for this article to be further copied/distributed or hosted elsewhere without the express permission from Springer. 
Goat anti-mouse IgG peroxidase conjugate (BioRad, Hercules, CA, USA) at a 1:5,000 dilution was used to visualize antibody-bound His portions of the recombinant proteins on Film. Unless otherwise stated, for immunoblot analyses using anti-EARLI1 antibodies, the reducing agent $\beta$-mercaptoethanol (Sigma) was omitted from the loading buffer. Total plant protein was isolated in Laemmli buffer from frozen plant tissue ground to a fine powder and quantified by the Bio-Rad Dc Protein Assay (BioRad), as described previously (Danyluk et al. 1998). Protoplasts used for protein isolation were prepared from 20 rosette leaves of 3-week-old Col-0 wild type plants before or after $3 \mathrm{~d}$ of cold treatment as described previously (http://www.genetics.mgh.harvard.edu/sheenweb). Equal amounts of protein were separated by $16 \%$ SDS-PAGE, electrotransferred to $0.45-$ $\mathrm{Jm}$ nitrocellulose membranes, and incubated for $2 \mathrm{~h}$ at room temperature with the anti-EARLI1 antiserum (1:500 dilution). Goat anti-rabbit IgG peroxidase conjugate (Sigma) at a 1:5,000 dilution was used to visualize the antibody-bound proteins on Film. For some experiments, anti-EARLI1 antiserum was affinity-purified as described (Sambrook et al. 1989). Briefly, total protein from cold acclimated 3weekold Col-FRI-Sf2 plants was separated by $16 \%$ SDS-PAGE and transferred to a nitrocellulose membrane. The membrane area where the EARLI1 monomers were located (tested on separate membranes by immunoblots) was cut out and used as "bait" to bind the antiEARLI1 antibody molecules in the antiserum. After incubation for 3 days at $4^{\circ} \mathrm{C}$, bound antibodies were washed off by changing the $\mathrm{pH}$ of the solution from 7.2 to 2.8 . The affinity-purified antiserum was readjusted to neutral $\mathrm{pH}$ before use.

\section{EARLI1::GFP construction and GFP Fluorescence detection by confocal microscopy analysis}

PCR was performed on EARLI1 CDNA using PCR primers 5'CATGCCATGGCTTCAAAGAACTCAGCCTC-3' and 5'CATGCCATGGCAGCACATTGG-AAGCCAGACG-3' (NcoI sites underlined). PCR products were digested with NcoI and ligated into pAVA393 containing GFP-5 (von Arnim et al. 1998). The EARLI1::GFP construct was digested with BamHI and HindIII, ligated into binary vector pPZP211 (Hajdukiewicz et al. 1994), and introduced into ABI for plant transformation.

Planta, Vol. 227, No. 1 (December 2007): pg. 233-243. DOI. This article is (C) Springer and permission has been granted for this version to appear in e-Publications@Marquette. Springer does not grant permission for this article to be further copied/distributed or hosted elsewhere without the express permission from Springer. 
Five-day-old long-day grown seedlings were used for GFP detection analyses. Plant roots were mounted directly in $\mathrm{dd}_{2} \mathrm{O}$. GFP Fluorescence was excited at $488 \mathrm{~nm}$ by a blue laser and detected at 505-530 nm using a Zeiss confocal microscope (Axiovert 200 with LSM 5 Pascal software). Images were taken by either 40 or $60 \times$ oilimmersion objectives. Each picture was taken as a slice of a Z-stack, at about $1 \mu \mathrm{m}$ thickness, as recommended by the manufacturer. At least ten individual plants from each genetic background were examined.

\section{Results}

\section{Cold acclimation response of EARLI1 knockdown lines}

EARLI1 gene expression is controlled by a multitude of environmental cues (Richards and Gardner 1995; Wilkosz and Schläppi 2000; Bubier and Schläppi 2004). Among those signals, cold was previously shown to highly upregulate and then persistently maintain the steady-state transcript levels of EARLI1 mRNA (Wilkosz and Schläppi 2000; Bubier and Schläppi 2004). It was previously shown that when stressed by freezing temperatures, non-acclimated plant lines overexpressing EARLI1 from the strong and constitutive cauliflower mosaic virus (CaMV) 35 S promoter leaked fewer electrolytes compared to the wild-type plants, suggesting that the gene may play a role in protecting plant cells by stabilizing cell membrane structures (Bubier and Schläppi 2004). To further investigate the function of EARLI1, a plant line in which EARLI1 expression was knocked-down by the RNA interference (RNAi) mechanism was analyzed. The RNAi construct was designed to target the eight-cysteine-motif ( $8 \mathrm{CM})$ region of EARLI1 with strong similarity to the other three closely related EARLI1-LIKE genes, which might have aVected their expression levels as well. To confirm this, transcript levels in the RNAi and wild-type lines were compared by RNA gel blot analysis. As shown in Fig. 2, transcript levels of At4g12470, EARLI1 (At4g12480), At4g12490 and At4g12500 were all lower in coldacclimated RNAi knockdown than in wild-type plants, although all genes, most visibly At4g12470, were still cold inducible in the knockdown plants. However, cold-acclimated RNAi plants had a

Planta, Vol. 227, No. 1 (December 2007): pg. 233-243. DOI. This article is @ Springer and permission has been granted for this version to appear in e-Publications@Marquette. Springer does not grant permission for this article to be further copied/distributed or hosted elsewhere without the express permission from Springer. 
tendency to leak more electrolytes at freezing temperatures than wildtype plants, suggesting that their cold acclimation response was at least partially affected by the downregulation of EARLI1 genes (Fig. 3).

\section{Freezing survival rates of yeast cells overexpressing EARLI1 genes}

To determine the potential contribution of individual EARLI1 genes in protecting cells against freezing damage, At4g12470, EARLI1, At4g12490, and At4g12500 were individually expressed in the budding yeast $S$. cerevisiae, and survival of cells was tested after a 24-h freezing period. Compared to yeast cells containing only empty pESCURA plasmids, cells harboring either EARLI1, At4g12490, or At4g12500 had a statistically significant $(P<0.05)$ increase in survival rates after a 24-h freezing period (Fig. 4). While not significant, yeast cells containing At4g12470 also had a tendency to improve freezing survival rates. These data indicated that EARLI1 and at least two of its paralogs protect heterologous yeast cells against freezing death.

To determine whether the myc-tagged EARLI1 and myc-tagged EARLI1-LIKE recombinant proteins were expressed in S. cerevisiae, immunoblot analyses using anti-myc antibodies and anti-EARLI1 antiserum were done. As shown in Fig. 5a, each recombinant protein was detectable by anti-myc antiserum, indicating that the proteins were produced at various levels in the yeast cells subjected to freezing stress. When the same protein fractions were incubated with antiEARLI1 antiserum, EARLI1 and At4g12470, but not At4g12490 or At4g12500, were recognized by the antiserum (Fig. 5b). This suggested that the polyclonal anti-EARLI1 antibodies crossreacted with the more closely related paralog At4g12470, but not with At4g12490 and At4g12500, which are more closely related to each other than to EARLI1 or At4g12470 (Fig. 1).

\section{Biochemical characterization of EARLI1 proteins}

To begin characterizing native EARLI1 proteins, poly-clonal anti$E A R L I 1$ antibodies were used to analyze proteins isolated from Arabidopsis plants. Anti-EARLI1 antiserum recognized a single band when proteins from cold-acclimated wild type or EARLI1

Planta, Vol. 227, No. 1 (December 2007): pg. 233-243. DOI. This article is @ Springer and permission has been granted for this version to appear in e-Publications@Marquette. Springer does not grant permission for this article to be further copied/distributed or hosted elsewhere without the express permission from Springer. 
overexpressing plants were analyzed by SDS-PAGE using loading buffer with the reducing agent $\beta$-mercaptoethanol ( $\beta$-ME) (Fig. 6a). However, when the reducing agent was omitted from the loading buffer, both apparent monomers and higher order complexes were recognized by the antiEARLI1 antiserum in proteins from coldacclimated wild-type or EARLI1 overexpressing plants, but not in proteins from RNAi plants (Fig. 6b). Thus, the abundance of the monomers and higher order protein complexes recognized by antiEARLI1 antiserum was depended on the genetic background and temperature treatment of different Arabidopsis lines, and correlated well with RNA transcript levels in those lines (Fig. 2). As shown in Fig. 6c, higher molecular weight bands were still detectable in proteins from cold acclimated plants probed with anti-EARLI1 antiserum that was affinity-purified using EARLI1 monomers cut out from SDS-PAGE gels (see Materials and methods). A protein band of approximately twice the size of an EARLI1 monomer was the most abundant band seen in immunoblots probed with the affinity-purified antiserum. This suggested that EARLI1 in Arabidopsis possibly interacts with itself and/or other proteins such as At4g12470 to form larger protein complexes.

Because it was reported that green tissues such as leaves and petioles are more competent to cold acclimate than roots (Chen et al. 1983), the tissue-specific expression profile of EARLI1 was determined. There was indeed a higher amount of EARLI1 protein in green tissues than in roots (Fig. 6d). This indicated that EARLI1 is expressed ubiquitously, but preferentially in cold-acclimation competent tissues.

To further study the EARLI1 protein at the molecular level, a His-tagged EARLI1 fusion protein was expressed in E. coli. A majority of the recombinant EARLI1 protein was always found in insoluble fractions, presumably as a result of sequestration into inclusion bodies (data not shown). Considering that formation of inclusion bodies might result from the absence of proper disulfide bond formation of proteins in the $E$. coli cytoplasm, different strategies were used to either direct the recombinant protein to the periplasmic region, or to promote the formation of disulfide bonds in the cytoplasm by using an $E$. coli strain with a more oxidizing cytoplasmic environment. However, neither of

Planta, Vol. 227, No. 1 (December 2007): pg. 233-243. DOI. This article is @ Springer and permission has been granted for this version to appear in e-Publications@Marquette. Springer does not grant permission for this article to be further copied/distributed or hosted elsewhere without the express permission from Springer. 
these strategies helped to improve the solubility of EARLI1 (data not shown), suggesting that different redox environments did not affect its solubility. Together with the hydropathy profile of EARLI1, these experimental results suggested that EARLI1 is a hydrophobic protein or prone to form insoluble aggregates. As shown in Fig. 7, when the proline-rich domain (PRD) and the 8CM region of EARLI1 were expressed separately as His-tagged recombinant proteins in $E$. coli, the solubility of the two domains became distinct. While the PRD was completely soluble (Fig. 7a), the 8CM domain was almost exclusively found in the insoluble fraction (Fig. 7b), suggesting that this region is either highly hydrophobic or aggregates easily in solution. Regardless of the solubility, besides apparent monomers higher order complexes were detected for both EARLI1 peptide domains in the immunoblot analyses. When protein samples were treated with the reducing agent $\beta$-ME, the PRD complexes were resolved into apparent monomers, while the $8 \mathrm{CM}$ region was largely unaffected by the treatment.

\section{Analysis of the EARLI1 localization in Arabidopsis cells}

The presence of a signal peptide in the conceptual amino acid sequence of EARLI1 suggests that it is a secreted protein, which would correlate well with $E A R L I 1$ 's hypothetical role of protecting the plasma membrane and/or cell wall structures. To test whether EARLI1 is a secreted protein, the localization pattern of EARLI1 was analyzed using an EARLI1-GFP fusion protein and confocal microscopy. GFP Fluorescence was found at peripheral regions in EARLI1-GFP expressing root cells (Fig. 8a), but not in wild type plants (Fig. 8c). A similar cell peripheral localization pattern was observed in root hair cells of cold-acclimated plants using anti-EARLI1 antiserum and immunohistochemical analysis (unpublished results). To determine whether EARLI1 localized to the plant cell wall or plasma membrane, cell walls were removed from cold-acclimated wild-type leaves and protoplasts were isolated. When equal amounts of proteins from whole cells and protoplasts were incubated with anti-EARLI1 antiserum, only a small amount of EARLI1 protein was detected in protoplasts (Fig. $8 \mathrm{e})$. Taken together, this suggested that EARLI1 is secreted into the cell wall, but may also have some affinity for the plasma membrane.

Planta, Vol. 227, No. 1 (December 2007): pg. 233-243. DOI. This article is @ Springer and permission has been granted for this version to appear in e-Publications@Marquette. Springer does not grant permission for this article to be further copied/distributed or hosted elsewhere without the express permission from Springer. 
NOT THE PUBLISHED VERSION; this is the author's final, peer-reviewed manuscript. The published version may be accessed by following the link in the citation at the bottom of the page.

\section{Discussion}

\section{Genetic analysis of EARLI1 type genes}

Our previous studies have shown that overexpression of the cold responsive gene EARLI1 partially improved freezing tolerance of nonacclimated Arabidopsis plants (Bubier and Schläppi 2004). We thus reasoned that a knockout of EARLI1 might have a negative effect on freezing tolerance of cold acclimated plants. A practical problem with testing this hypothesis was that EARLI1 belongs to a family of four closely related and possibly functionally redundant genes (Fig. 1). We therefore used here an Arabidopsis line in which all four EARLI1 type genes were knocked down by the RNAi mechanism and observed indeed a trend for increased freezing damage at temperatures between -4 to $-7^{\circ} \mathrm{C}$, and -10 to $-12^{\circ} \mathrm{C}$ (Fig. 3). However, except for $-11^{\circ} \mathrm{C}$, the difference was not significant $(P>0.05)$. A reason for this may be that the EARLI1 type genes were still inducible to varying degree in cold acclimated RNAi plants (Fig. 2), and further experiments are needed to determine whether the observed trend becomes statistically significant in individual knockout plants or in lines in which all genes are knocked out. These experiments will be technically challenging, because the four EARLI1 type genes are linked in a tandem array at the same chromosomal location. Nevertheless, together with our previous gain-of-function results (Bubier and Schläppi 2004), the trend observed in Fig. 3 suggests that EARLI1 genes play a role in freezing tolerance of cold acclimated Arabidopsis plants. Their role may be most important at non-lethal freezing temperatures, that is, when frozen cells leak less than $50 \%$ electrolytes ( -4 to $-7^{\circ} \mathrm{C}$, Fig. 3 ).

To determine the individual contribution of EARLI1 type genes to freezing tolerance, all four genes were individually expressed in the yeast $S$. cerevisiae. We chose yeast because its genome does not have any HyPRP genes, and it was previously shown that putative stress tolerance genes from plants have the potential to increase the freezing survival of S. cerevisiae cells (Imai et al. 1996; Zhang et al. 2000). Our observation that EARLI1 significantly $(P<0.05)$ protected yeast from freezing death (Fig. 4) was in agreement with our previous studies on Arabidopsis plants (Bubier and Schläppi 2004). It was also

Planta, Vol. 227, No. 1 (December 2007): pg. 233-243. DOI. This article is @ Springer and permission has been granted for this version to appear in e-Publications@Marquette. Springer does not grant permission for this article to be further copied/distributed or hosted elsewhere without the express permission from Springer. 
in agreement with the recent report that DEA1, a HyPRP from tomato, significantly increased freezing survival of $P$. pastoris cells, a less commonly used yeast system (Weyman et al. 2006b). DEA1 increased freezing survival three- to fourfold compared to the twofold increase observed for EARLI1 proteins (Fig. 4). One difference between the two experiments was that DAE1 was expressed as a fusion protein containing the yeast a-factor signal sequence, whereas EARLI1 contained its own putative signal sequence. Future experiments will be necessary to determine whether different signal sequences fused to EARLI1 influence the frequency of yeast freezing survival. Our experiments moreover showed that At4g12490 and At4g12500, two of the other three cold responsive EARLI1 type genes, also significantly protected yeast cells from freezing death, while At4g12470 had only a non-significant tendency toward protection (Fig. 4). Interestingly, it was shown in Arabidopsis that EARLI1, At4g12490, and At4g12500 had the same co-expression profile in response to cold, while At4g12470 belonged to a different class of cold responsive genes (Vogel et al. 2005). Thus, it may be that EARLI1, At4g12490, and At4g12500 have a more significant role in protecting plant and yeast cells from freezing damage than At4g12470, which can be tested in future experiments using transgenic plants. Another difference between At4g12470 and the other three proteins is that it is the smallest protein with the shortest PRD (Fig. 1). Future domain swap experiments will be necessary to determine whether the length and type of PRD has a positive or negative effect on the potential of EARLI1 type proteins to protect yeast cells from freezing death.

\section{Biochemical analysis of EARLI1 proteins}

For biochemical analysis of EARLI1 proteins, we generated antiEARLI1 antiserum and used it in immunoblot analysis of proteins isolated from different tissues and Arabidopsis lines. Anti-EARLI1 antiserum cross-reacted with At4g12470 (Fig. 5), which may be explained with the high degree of amino acid identity between the two proteins. The PRD-8CM fragment of EARLI1 used for antiserum production is $92 \%$ identical to At4g12470, whereas it is only 79 and $83 \%$ identical to At4g12490 and At4g12500, respectively. Thus, crossreactivity to At4g12470 needs to be taken into consideration when

Planta, Vol. 227, No. 1 (December 2007): pg. 233-243. DOI. This article is @ Springer and permission has been granted for this version to appear in e-Publications@Marquette. Springer does not grant permission for this article to be further copied/distributed or hosted elsewhere without the express permission from Springer. 
discussing immunoblots using proteins from cold acclimated Arabidopsis plants.

Under reducing conditions, the EARLI1 protein profile (Fig. 6a) correlated well with the steady-state levels of EARLI1 mRNA observed here (Fig. 2) and in previous studies (Wilkosz and Schläppi 2000; Bubier and Schläppi 2004). We noticed, however, that the immunoblots needed to be exposed on Film for a relatively long time ( $\sim 10 \mathrm{~min}$ ) to detect EARLI1 protein signals. It is commonly accepted that under oxidizing conditions the 8CM domains of HyP-RPs form four intramolecular disulfide bonds, which were shown to be critical for establishing the correct protein conformation and essential for 8CM protein function (Kader 1996; Josè-Estanyol et al. 2004). Because the anti-EARLI1 antiserum most likely was raised against an oxidized form of $E A R L I 1$, we suspected that it was less reactive against its reduced form in which the disulfide bonds were broken by $\beta$-ME. Indeed, omission of $\beta$-ME from the loading buffer not only improved the reactivity of the antiserum, but to our surprise also revealed a series of protein bands that were larger in size than the molecular weight (MW) of EARLI1 or At4g12470 (Fig. 6b). Even the putative monomer forms of EARLI1 and At4g12470 appeared larger on 16\% SDS-PAGE gels than their predicted sizes. Assuming cleavage of the signal peptide, EARLI1 and At4g12470 are predicted to have a MW of 14.7 and $14.1 \mathrm{kDa}$, respectively. However, in non-acclimated or EARLI1 overexpressing plants the smallest protein band had an apparent $M W$ of $\gg 19 \mathrm{kDa}$. In cold-acclimated plants, we often observed a second band of $\sim 17 \mathrm{kDa}$, which may correspond to At4g12470 or another cold induced protein. The $19 \mathrm{kDa}$ size of the predominant band cannot be explained with retention of the signal peptide in At4g12470 or EARLI1 proteins, because the predicted full-length proteins would have a MW of 16.8 and $17.3 \mathrm{kDa}$, respectively. In yeast, myc-tagged EARLI1 proteins also appeared larger on SDSPAGE gels than their predicted MW (Fig. 5), even when the signal peptide sequence is included in the MW calculation. This suggests that even in the presence of SDS, EARLI1 proteins may not be completely unfolded, leading to a retarded mobility during gel electrophoresis. Alternatively, the proteins may be posttranslationally modified in yeast and plants, as previously suggested for recombinant DEA1 protein expressed in the yeast $P$. pastoris (Weyman et al. 2006b). EARLI1 and At4g12470 are predicted

Planta, Vol. 227, No. 1 (December 2007): pg. 233-243. DOI. This article is @ Springer and permission has been granted for this version to appear in e-Publications@Marquette. Springer does not grant permission for this article to be further copied/distributed or hosted elsewhere without the express permission from Springer. 
to have at least five phosphorylation sites in the PRD, whereas ten sites are predicted for At4g12490 and At4g12500 (Blom et al. 1999). A differential amount of putatively phosphorylated sites might explain, at least in part, why At4g12490myc and At4g12500-myc proteins expressed in yeast appear about $10 \mathrm{kDa}$ larger than EARLI1-myc and At4g12470-myc, although theoretically there is only a $1-2 \mathrm{kDa}$ size difference between the two pairs of proteins.

The higher order bands observed with anti-EARLI1 antiserum most likely contain EARLI1, because compared to wild type they are more abundant in EARLI1 overexpressing, non-acclimated plants, and are virtually absent in RNAi knockdown plants (Fig. 6b). Moreover, these bands were still detected with antiserum that was affinity purified against the apparent monomer form of EARLI1 (Fig. 6c). Taken together, this suggests that the antiserum is specific for EARLI1 and may cross-react with At4g12470, but not with other high molecular weight proteins. Our observation that the high molecular weight bands are absent in immunoblots using reduced proteins suggests that disulfide bonds might be involved in their formation. Our observation that in E. coli the PRD of EARLI1 forms higher order complexes that can be resolved into apparent monomers with $\mathrm{p}-\mathrm{ME}$ (Fig. 7) raises the possibility that this region may participate in intermolecular disulfide bond formation. In agreement with this, EARLI1 type proteins have two conserved cysteines at the beginning of their PRD regions (Fig. 1). Whether these cysteines are involved in disulfide bond formation can be tested in future experiments using site-directed mutagenesis.

In agreement with its hydropathy profile, the recombinant $6 \mathrm{His}-$ PRD EARLI1 fragment was completely soluble whereas the $6 \mathrm{His}-8 \mathrm{CM}$ fragment was mostly insoluble (Fig. 7). This suggests that the two domains have the potential to interact with cellular compartments of different hydropathy. If EARLI1proteins are secreted into the extracellular space, as indicated by our EARLI1-GFP Fluorescence and immunoblot analyses using protoplasts (Fig. 8), it is possible that their PRDs prefer to associate with hydrophilic cell wall structures, whereas the $8 \mathrm{CM}$ domains may interact with the hydrophobic plasma membrane. This hypothetical cell wall-plasma membrane association could be explained with the dual hydropathy of its two domains. A

Planta, Vol. 227, No. 1 (December 2007): pg. 233-243. DOI. This article is @ Springer and permission has been granted for this version to appear in e-Publications@Marquette. Springer does not grant permission for this article to be further copied/distributed or hosted elsewhere without the express permission from Springer. 
similar association pattern was previously proposed for a cold induced HyPRP from rapeseed (Goodwin et al. 1996) and for a salt-inducible HyPRP from alfalfa (Deutch and Winicov 1995). Both fragments also produced multiple bands on SDS-PAGE gels, possibly due to posttranslational modifications or, as discussed above for the PRD, disulfide formation involving cysteines. Addition of $\beta$-ME had only a minor effect on the $6 \mathrm{His}-8 \mathrm{CM}$ protein bands, suggesting that the cysteines in the $8 \mathrm{CM}$ are mostly involved in intramolecular disulfide bond formation. Our results suggest that the tendency to form disulfide bonds in $E$. coli is higher for the PRD, because it produced more complexes in proportion to apparent monomers than the $8 \mathrm{CM}$ domain. Even in the presence of reducing agents the apparent monomer size of each recombinant domain was twice as large as its predicted MW (18 kDa apparent vs. $9.1 \mathrm{kDa}$ calculated for 6His-PRD; 24 kDa apparent vs. $12.7 \mathrm{kDa}$ calculated for 6His-8CM; Fig. 7). The reason for this is currently unknown, but it appears that the recombinant protein fragments run as SDS-PAGE/ $\beta$-ME-stable dimers when expressed in $E$. coli.

In this work, we present to the best of our knowledge the First evidence that $E A R L I 1$, a member of the HyPRP family, and possibly its paralog At4g12470 form higher order protein complexes in plants. The capability of EARLI1 to form complexes is presumably also a property of its closely related family members, which might be a universal mechanism exploited by proteins with a similar structure to protect the cell periphery in response to environmental stresses. Because of its overall hydrophobic and insoluble nature, EARLI1 proteins may form aggregates in the extracellular space. An "agglutination" effect was previously proposed for extensins (Showalter 1993), and might also be a property of some HyPRPs. It is therefore conceivable that EARLI1 and its paralogs use this agglutination effect as a protective mechanism against cellular damage, for example by filling pores in the cell wall to inhibit propagation of ice through the cell wall during freezing stress. Another possibility may be that the cysteines in EARLI1 monomers act as reactive oxygen species scavengers to protect lipids in the plasma membrane and other proteins in the cell wall from oxidative stress. Alternatively, EARLI1 and its paralogs may protect plant cells by inhibiting proteases secreted during stress into the extracellular space, as previously proposed for other members of

Planta, Vol. 227, No. 1 (December 2007): pg. 233-243. DOI. This article is @ Springer and permission has been granted for this version to appear in e-Publications@Marquette. Springer does not grant permission for this article to be further copied/distributed or hosted elsewhere without the express permission from Springer. 
8CM domain-containing proteins (Endo et al. 2001). The two distinct domains of EARLI1, both of which have cysteines, may be the result of evolutionary domain innovation (Karev et al. 2002), in which two peptide domains, one usually associated with the cell wall, the other possibly associated with the plasma membrane, converged into one protein to better fulfill the task of protecting cells from environmental stresses. Identification of possible partner(s) that interact with oxidized and agglutinated EARLI1 proteins may become important for our understanding of the cell defense mechanisms utilized against different environmental stresses.

\section{Acknowledgment}

We are grateful to J. Anderson (Marquette University, Milwaukee, WI, USA) and members of his lab for help with yeast experiments; to J. Bubier and G. T. Hayman (Marquette University) for generating EARLI1 knockdown lines; to M. Nagao (Iwate University, Morioka, Japan) for help with the electrolyte leakage assays; and to Y. Pan (Marquette University) for protoplast preparation. The phosphorimager was provided by NSF Instrumentation grant No. D.B.I. 0100667 . This research was supported by NRI Competitive Grant No. 2001-35100-10688 from the US Department of Agriculture.

\section{References}

Blom N, Gammeltoft S, Brunak S (1999) Sequence-and structure-based prediction of eukaryotic protein phosphorylation sites. J Mol Biol 294:1351-1362

Bubier J, Schläppi M (2004) Cold induction of EARLI1, a putative Arabidopsis lipid transfer protein, is light and calcium dependent. Plant Cell Environ 27:929-936

Chen THH, Gusta LV, Fowler DB (1983) Freezing injury and root development in winter cereals. Plant Physiol 73:773-777

Danyluk J, Perron A, Houde M, Limin A, Fowler B, Benhamou N, Sarhan F (1998) Accumulation of an acidic dehydrin in the vicinity of the plasma membrane during cold acclimation of wheat. Plant Cell 10:623-638

Deutch CE, Winicov I (1995) Post-transcriptional regulation of a salt-inducible alfalfa gene encoding a putative chimeric proline-rich cell wall protein. Plant Mol Biol 27:411-418

Endo S, Demura T, Fukuda H (2001) Inhibition of proteasome activity by the TED4 protein in extracellular space: a novel mechanism for protection

Planta, Vol. 227, No. 1 (December 2007): pg. 233-243. DOI. This article is C Springer and permission has been granted for this version to appear in e-Publications@Marquette. Springer does not grant permission for this article to be further copied/distributed or hosted elsewhere without the express permission from Springer. 
NOT THE PUBLISHED VERSION; this is the author's final, peer-reviewed manuscript. The published version may be accessed by following the link in the citation at the bottom of the page.

of living cells from injury caused by dying cells. Plant Cell Physiol 42:9-19

Gleave AP (1992) A versatile binary vector system with a T-DNA organisational structure conducive to eYcient integration of cloned DNA into the plant genome. Plant Mol Biol 20:1203-1207

Goodwin W, Pallas JA, Jenkins GI (1996) Transcripts of a gene encoding a putative cell wall-plasma membrane linker protein are specifically coldinduced in Brassica napus. Plant Mol Biol 31:771-781

Hajdukiewicz P, Svab Z, Maliga P (1994) The small, versatile $p P Z P$ family of Agrobacterium binary vectors for plant transformation. Plant Mol Biol 25:989-994

Imai R, Chang L, Otha A, Bray EA, Takagi M (1996) A lea-class gene of tomato confers salt and freezing tolerance when expressed in Saccharomyces cerevisiae. Gene 170:243-248

Josè-Estanyol M, Gomis-Ruth FX, Puigdomenech P (2004) The eight-cysteine motif, a versatile structure in plant proteins. Plant Physiol Biochem 42:355-365

Kader J-C (1996) Lipid-transfer proteins in plants. Annu Rev Plant Physiol Plant Mol Biol 47:627-654

Karev GP, Wolf YI, Rzhetsky AY, Berezovskaya FS, Koonin EV (2002) Birth and death of protein domains: a simple model of evolution explains power law behavior. BMC Evol Biol 2:18

Lee I, Amasino RM (1995) Effect of vernalization, photoperiod, and light quality on the flowering phenotype of Arabidopsis plants containing the FRIGIDA gene. Plant Physiol 108:157-162

Murashige T, Skoog F (1962) A revised medium for rapid growth and bioassay with tobacco tissue cultures. Physiol Plant 15:473-497

Reeves PH, Coupland G (2000) Response of plant development to environment: control of Xowering by daylength and temperature. Curr Opin Plant Biol 3:37-42

Richards KD, Gardner RC (1995) pEARLI1: an Arabidopsis member of a conserved gene family. Plant Physiol 109:1497

Sambrook J, Maniatis T, Fritsch EF (1989) Molecular cloning: a laboratory manual, 2nd edn. Cold Spring Harbor Press, Cold Spring Harbor, NY

Showalter MA (1993) Structure and function of plant cell wall proteins. Plant Cell 5:9-23

Uemura M, Tominaga Y, Nakagawara C, Shigematsu S, Minami A, Kawamura $Y(2006)$ Responses of the plasma membrane to low temperatures. Physiol Plant 126:81-89

Veal EA, Ross SJ, Malakasi P, Peacock E, Morgan BA (2003) Ybp1 is required for the hydrogen peroxide-induced oxidation of the Yap1 transcription factor. J Biol Chem 278:30896-30904

Planta, Vol. 227, No. 1 (December 2007): pg. 233-243. DOI. This article is @ Springer and permission has been granted for this version to appear in e-Publications@Marquette. Springer does not grant permission for this article to be further copied/distributed or hosted elsewhere without the express permission from Springer. 
NOT THE PUBLISHED VERSION; this is the author's final, peer-reviewed manuscript. The published version may be accessed by following the link in the citation at the bottom of the page.

Vogel JT, Zarka DG, Van Buskirk HA, Fowler SG, Thomashow MF (2005) Roles of the CBF2 and ZAT12 transcription factors in configuring the low temperature transcriptome of Arabidopsis. Plant J 41:195-211

von Arnim AG, Deng XW, Stacey MG (1998) Cloning vectors for the expression of green fluorescent protein fusion proteins in transgenic plants. Gene 221:35-43

Warren G, McKown R, Marin AL, Teutonico R (1996) Isolation of mutations affecting the development of freezing tolerance in Arabidopsis thaliana (L.) Heynh. Plant Physiol 111:1011-1019

Wei H, Dhanaraj AL, Arora R, Rowland LJ, Fu Y, Sun L (2006) Identification of cold acclimation-responsive rhododendron genes for lipid metabolism, membrane transport and lignin biosynthesis: importance of moderately abundant ESTs in genomic studies. Plant Cell Environ 29:558-570

Weiser RL, Wallner SJ, Waddell JW (1990) Cell wall and extensin mRNA changes during cold acclimation of pea seedlings. Plant Physiol 93:1021-1026

Wesley SV, Helliwell CA, Smith NA, Wang MB, Rouse DT, Liu Q, Gooding PS, Singh SP, Abbott D, Stoutjesdigk PA, Robinson SP, Gleave AP, Green AG, Waterhouse PM (2001) Construct design for efficient, effective and high-throughput gene silencing in plants. Plant J 27:581-590

Weyman PD, Pan Z, Feng Q, Gilchrist DG, Bostock RM (2006a) A circadian rhythm-regulated tomato gene is induced by arachidonic acid and Phythophthora infestans infection. Plant Physiol 140:235-248

Weyman PD, Pan Z, Feng Q, Gilchrist DG, Bostock RM (2006b) DEA1, a circadian-and cold-regulated tomato gene, protects yeast cells from freezing death. Plant Mol Biol 62:547-559

Whitham SA, Wang Y (2004) Roles for host factors in plant viral pathogenicity. Curr Opin Plant Biol 7:365-371

Wilkosz R, Schläppi M (2000) A gene expression screen identifies EARLI1 as a novel vernalization-responsive gene in Arabidopsis thaliana. Plant Mol Biol 44:777-787

Yamada T, Kuroda K, Jitsuyama Y, Takezawa D, Arakawa K, Fujikawa S (2002) Roles of the plasma membrane and the cell wall in the responses of plant cells to freezing. Planta 215:770-778

Zhang L, Ohta A, Takagi M, Imai R (2000) Expression of plant group 2 and group 3 lea genes in Saccharomyces cerevisiae revealed functional divergence among LEA proteins. J Biochem 127:611-616

Zhang JH, Jia WS, Yang JC, Ismail AM (2006) Role of ABA in integrating plant responses to drought and salt stresses. Field Crops Res 97:111-119

Planta, Vol. 227, No. 1 (December 2007): pg. 233-243. DOI. This article is (c) Springer and permission has been granted for this version to appear in e-Publications@Marquette. Springer does not grant permission for this article to be further copied/distributed or hosted elsewhere without the express permission from Springer. 


\section{Appendix}

Figure 1: Alignment and phylogenetic tree of EARLI1 type proteins.

(a)

$$
\begin{aligned}
& 12490 \\
& 12500 \\
& \text { EARLI } 1 \\
& 12470 \\
& \\
& 12490 \\
& 12500 \\
& \text { EARLI1 } \\
& 12470 \\
& \\
& 12490 \\
& 12500 \\
& \text { EARLI } 1 \\
& 12470
\end{aligned}
$$

PRD

1 MASKKSASLALFFALILFFTLTAGTWCRCEPSPKPRPLFNPKVP S KVP

1 MASKNSTSLALFFALKILFFTTIATDCRCNLSPKPRTVPSPKVPSPKYP

1 MASKNSASTALFFALITFFTLAATDCGCNPSPKHKPVPSPKPKPVPSP

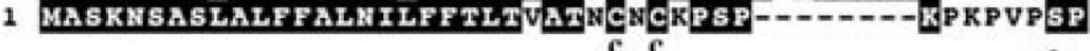

c c

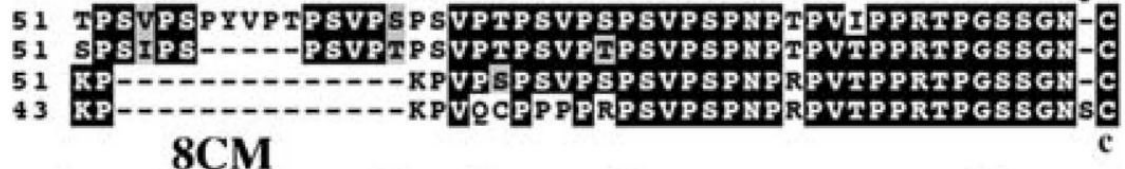

100 PIDALRLGVCAKVLSGLLEVOLGOPSPPCCSLIOGLVDLDARVCLCTAL

95 PIDALRLGVCANVL SLLKVOLGOP SAOPCCSLIOGLVDLDAAICLCTAL

86 PIDALRLGVCANVL SSLLNIOLGOPSAOPCCSLIOGLVDLDAA I CLCTAL

79 PIDALKLGVCANVLSSLLWIOLGOPSSGCCCSIOGLVDVAAICLCTAL

c C

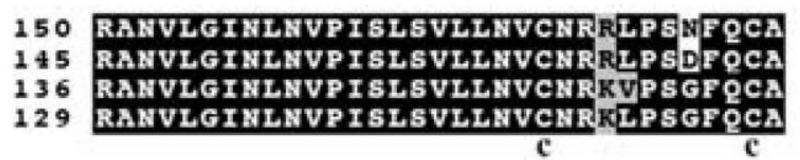

150 RAKVLGI:LEVISLSVLLFVCKRRLPSWFQCA

145 RAYVTGTHTHVPIST SUT THVCNBRIPSDFOCA

136 RAHVLGIMLNVPISLSVLLAVCHRKVPSGFOCA

c c

(b) $\left\{\begin{array}{l}\text { EARLI1 } \\ \text { At4g12470 } \\ \text { At4g12490 }_{\text {At4g12500 }}\end{array}\right.$

(a) CLUSTAL alignment. The bar above the alignment indicates the putative signal sequence for each protein. PRD proline-rich domain; $8 C M$ eightcysteine-motif. The star sign (*) indicates the end of the PRD and the beginning of the $8 \mathrm{CM}$ domain. Two conserved cysteines in the PRD and eight conserved cysteines in the $8 \mathrm{CM}$ are indicated below the alignment.

(b) N-J tree using AtEXT1 and AtLTP1 as outgroups (not shown) 
NOT THE PUBLISHED VERSION; this is the author's final, peer-reviewed manuscript. The published version may be accessed by following the link in the citation at the bottom of the page.

Figure 2: RNA gel blot analysis of EARLI1 type gene transcript abundance in Col-FRI-Sf2 wild type plants and RNAi knockdown lines.

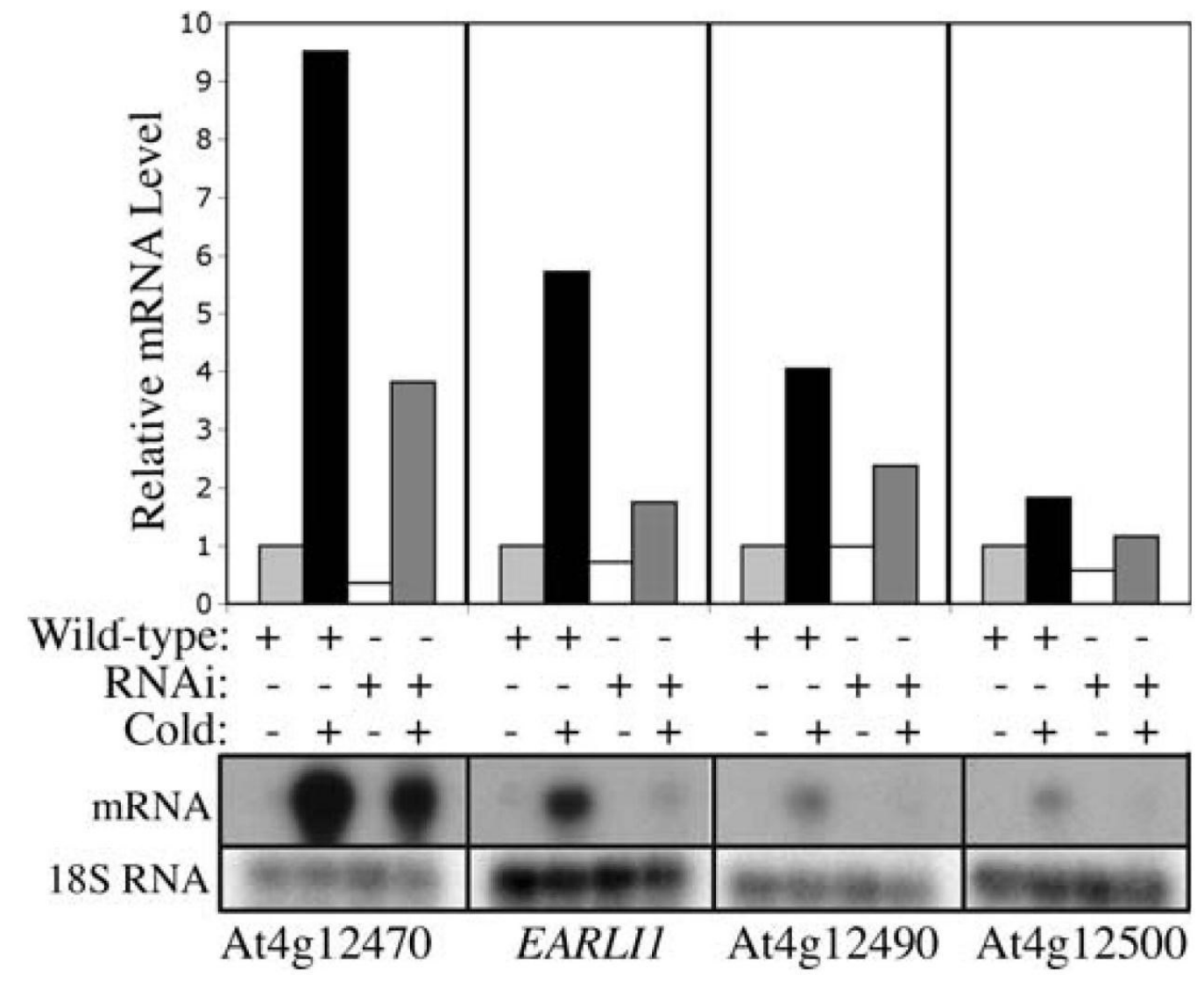

RNA blots were hybridized with probes specific for At4g12470, EARLI1, At4g12490, and A4g12500. The same blots were reprobed with $18 S$ rDNA to normalize RNA loading. RNA was isolated from plants grown at room temperature and from plants that were cold acclimated for one week at $4^{\circ} \mathrm{C}$. Band intensities were quantified using a phosphorimager and IMAGEQUANT software (Molecular Dynamics/ Amersham Bioscience) and normalized results are shown in graphic representation

Planta, Vol. 227, No. 1 (December 2007): pg. 233-243. DOI. This article is (c) Springer and permission has been granted for this version to appear in e-Publications@Marquette. Springer does not grant permission for this article to be further copied/distributed or hosted elsewhere without the express permission from Springer. 
NOT THE PUBLISHED VERSION; this is the author's final, peer-reviewed manuscript. The published version may be accessed by following the link in the citation at the bottom of the page.

Figure 3: Freezing tolerance of Col-FRI-Sf2 wild type plants and RNAi knockdown lines.

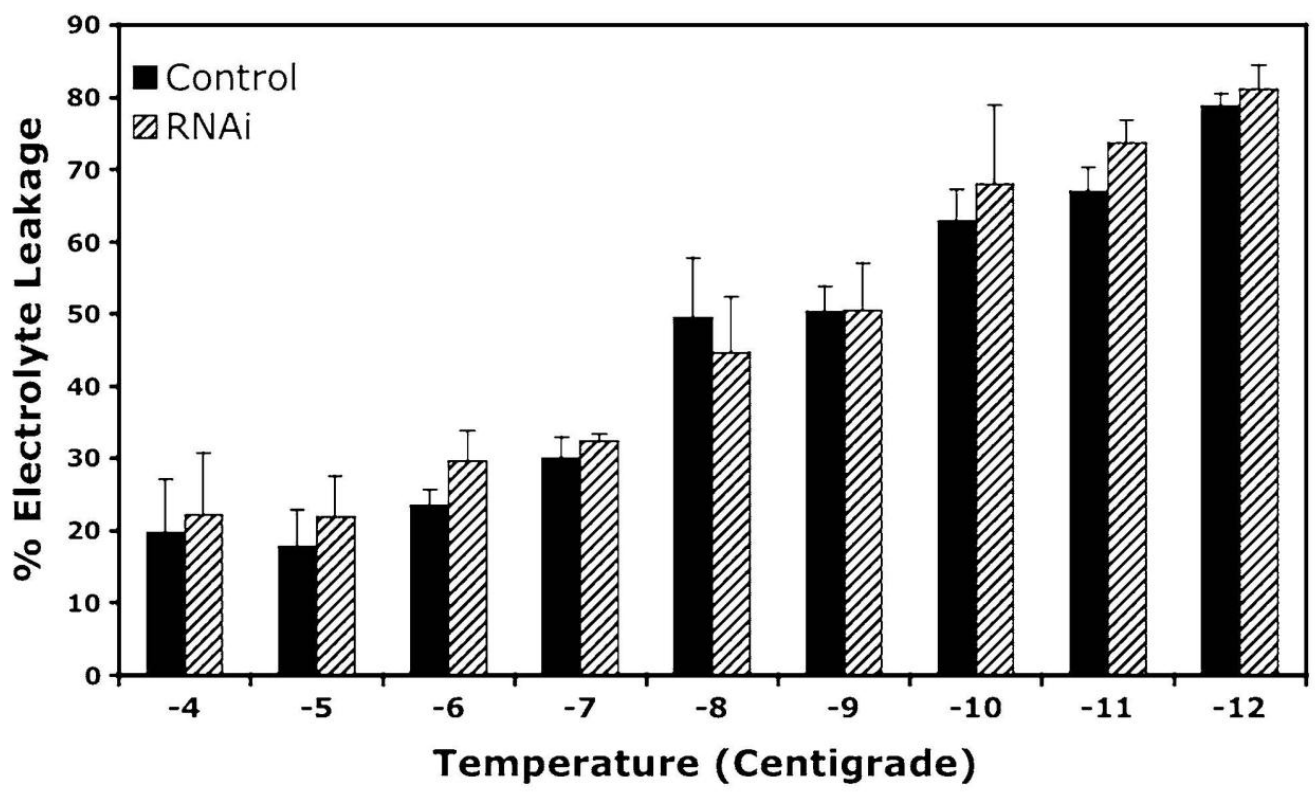

The electrolyte leakage assay was used to evaluate freezing tolerance of cold acclimated plants ( 3 days at $4^{\circ} \mathrm{C}$ ). Electrolyte leakage means \pm SE for three independent experiments are shown 
NOT THE PUBLISHED VERSION; this is the author's final, peer-reviewed manuscript. The published version may be accessed by following the link in the citation at the bottom of the page.

Figure 4: Freezing survival rates of $S$. cerevisiae cells expressing different EARLI1 type genes.

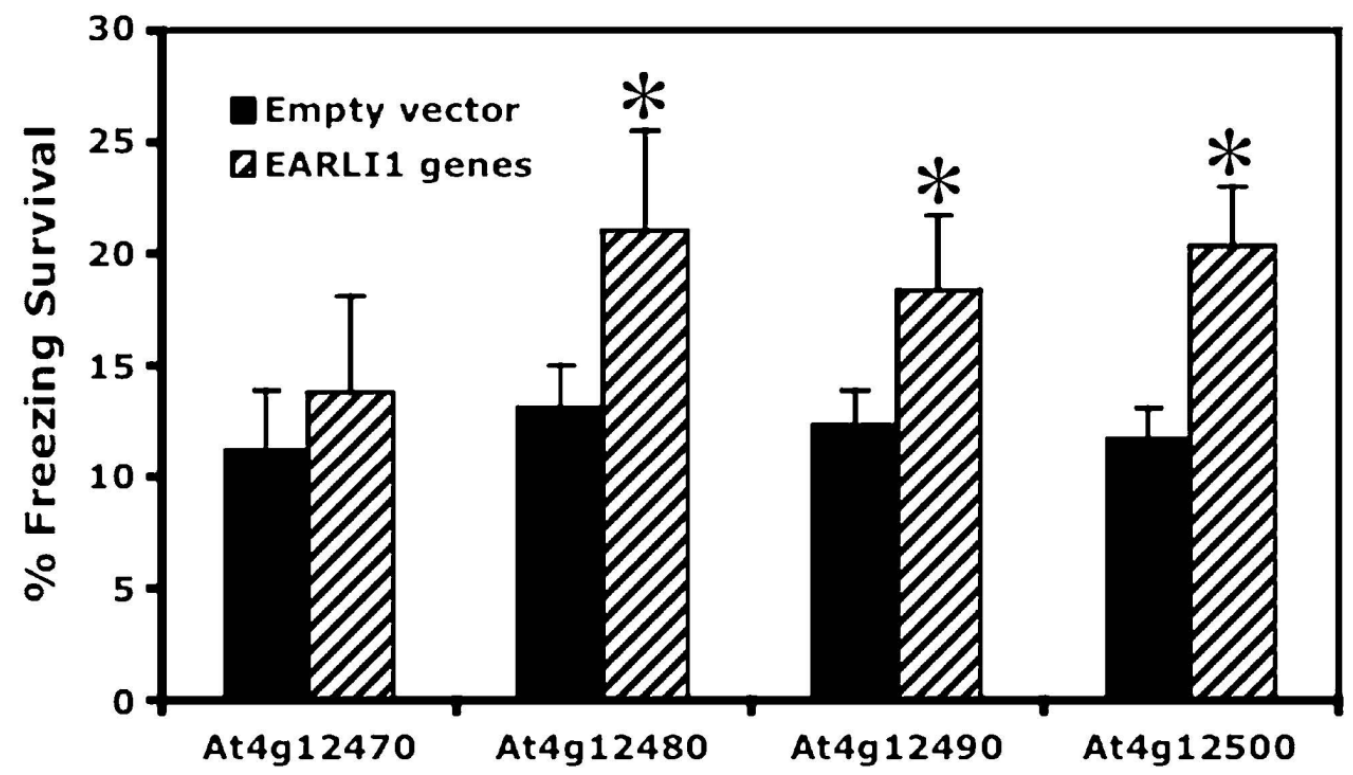

For each experiment, freezing survival of transformed yeast cells at $-20^{\circ} \mathrm{C}$ was compared to empty vector transformed control cells. Mean survival rates \pm SE are shown for 3-6 different experiments (At4g12470, $n=3$; At4g12480 $=$ EARLI1, $n=6$; At4g12490, $n=5$; At4g12500, $n=6)$. Significantly different treatment means $(P<0.05$, paired Student's $t$ test) are indicated with the star sign $(*)$ 
NOT THE PUBLISHED VERSION; this is the author's final, peer-reviewed manuscript. The published version may be accessed by following the link in the citation at the bottom of the page.

Figure 5: Immunoblot analysis of EARLI1 type proteins in yeast.

(a)

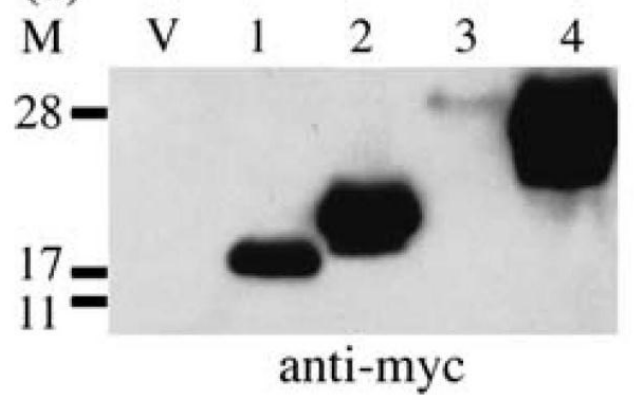

(b)

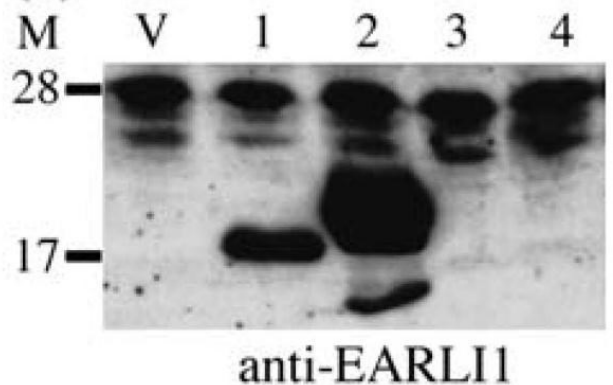

(a) Proteins were separated by SDS-PAGE and probed with mouse anti-myc antiserum to detect the recombinant proteins.

(b) Proteins were separated by SDS-PAGE and probed with rabbit antiEARLI1 antiserum to determine antiserum specificity. $M$ molecular marker (kDa); V vector control; lane 1 At4g12470; lane 2 EARLI1; lane 3 At4g12490; lane 4 At4g12500 
Figure 6: Immunoblot analysis of native EARLI1 proteins in Arabidopsis.

(a)

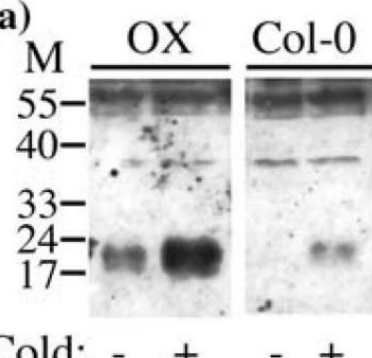

(c)

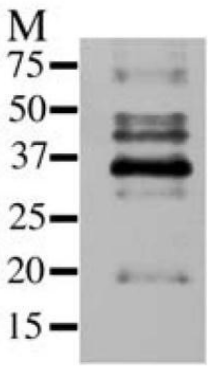

(b)

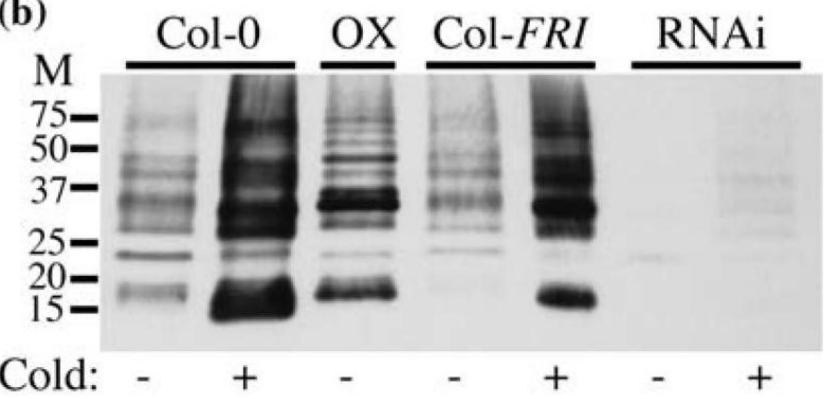

(d)

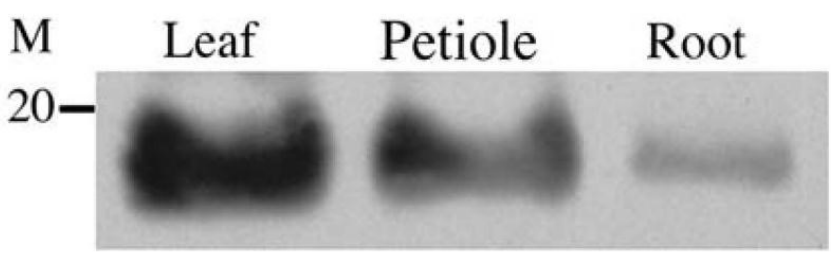

Proteins were quantified for equal loading using a detergent compatible protein assay (Danyluk et al. 1998). Proteins were separated by SDS-PAGE and probed with anti-EARLI1 antiserum.

a Analysis of EARLI1 proteins in the presence of $0.5 \%(\sim 700 \mathrm{mM})$ of the reducing agent $\beta$-mercaptoethanol ( $\beta$-ME) before $(-)$ or after $(+) 3$ days of cold acclimation at $4^{\circ} \mathrm{C}$. OX: 35S: :EARLI1 line in the Col-0 background. b Analysis of EARLI1 proteins in the absence of $\beta$-ME before (-) or after (+) 3 days of cold acclimation at $4^{\circ} \mathrm{C}$. OX: $35 \mathrm{~S}$ : :EARLI1 line in the Col-0 background; RNAi: EARLI1 knockdown line in the Col-FRI background. c Analysis of EARLI1 protein complexes using affinity-purified anti-EARLI1 antiserum (see Materials and methods). Total protein was extracted from 4week-old wild-type plants that were cold acclimated for 3 days at $4^{\circ} \mathrm{C}$. d Tissue-specific expression profile of EARLI1 proteins extracted from different tissues of 3-week-old wild type seedlings that were cold acclimated for 3 days at $4^{\circ} \mathrm{C}$. $M$ molecular marker (kDa) 
Figure 7: Immunoblot analysis of recombinant EARLI1 protein domains.

(a)

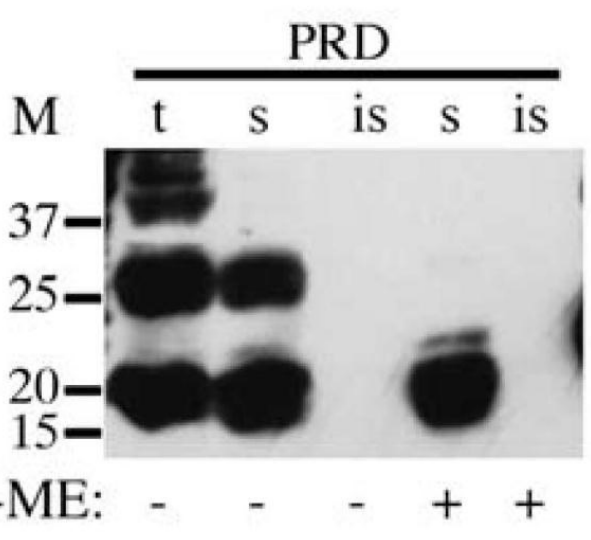

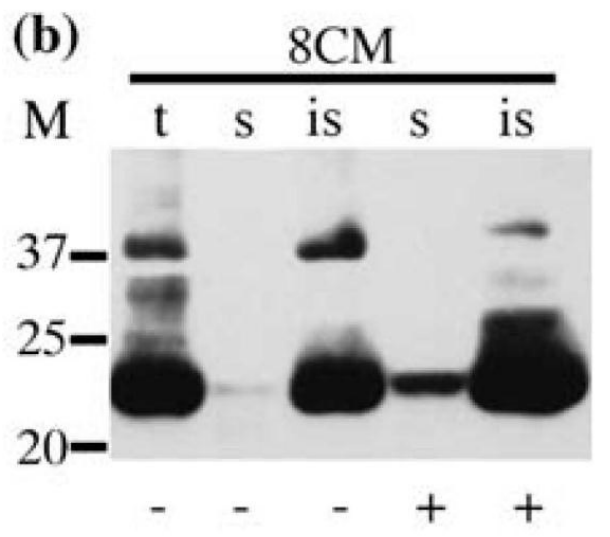

His-tagged recombinant protein domains were individually expressed in $E$. coli. Total protein $(t)$ was further separated into soluble $(s)$ and insoluble (is) protein fractions as described (Materials and methods). Protein fractions were mock treated $(-)$ or incubated for $10 \mathrm{~min}(+)$ with $0.5 \%(\sim 700 \mathrm{mM})$ of the reducing agent $\beta$-mercaptoethanol ( $\beta-\mathrm{ME})$. Proteins were separated by SDSPAGE and probed with anti-His antiserum.

a Analysis of the proline-rich domain $(P R D)$.

b Analysis of the eight-cysteine-motif $(8 C M)$ domain. $M$ molecular marker (kDa) 
NOT THE PUBLISHED VERSION; this is the author's final, peer-reviewed manuscript. The published version may be accessed by following the link in the citation at the bottom of the page.

Figure 8: Analysis of the subcellular localization of EARLI1 in Arabidopsis cells.
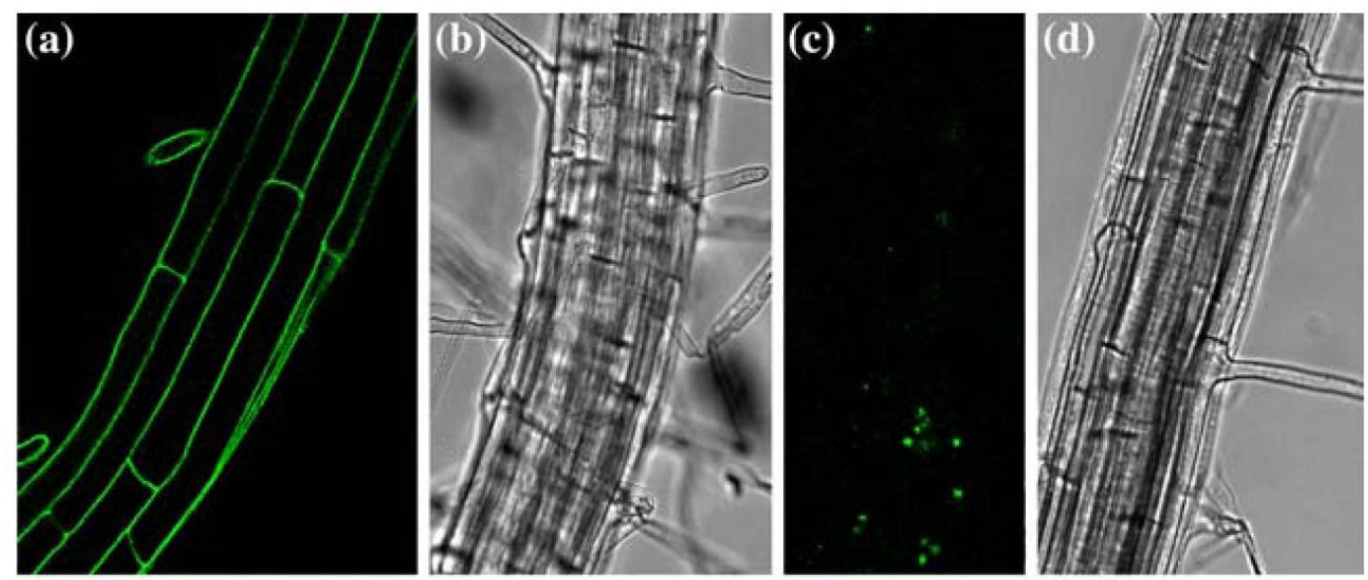

(e) $\begin{array}{lllll}M & \mathbf{T} & \mathbf{P P} & \mathbf{T} & \mathbf{P P}\end{array}$

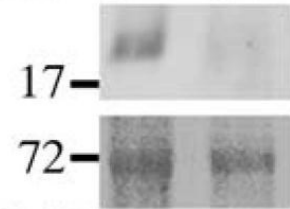

Cold: -

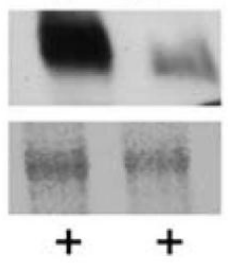

a, c Confocal microscopy images of GFP fluorescence of EARLI1-GFP protein in transgenic roots expressing 35S: :EARLI1- GFP (a), and in Col-0 wild-type (c) control roots.

b, d Bright-Weld image of cells shown in a and $\mathbf{c}$, respectively.

e. Upper panel Immunoblot analysis of EARLI1 protein in whole cells $(T)$ and protoplasts $(P P)$ of Col-0 wild-type plants before $(-)$ and after (+) 3 days of cold acclimation. Lower panel Ponceau S staining of an unknown abundant 72 $\mathrm{kDa}$ protein transferred to the membrane used for immunoblot analysis to show equal loading. $M$ molecular marker $(\mathrm{kDa})$

Planta, Vol. 227, No. 1 (December 2007): pg. 233-243. DOI. This article is C Springer and permission has been granted for this version to appear in e-Publications@Marquette. Springer does not grant permission for this article to be further copied/distributed or hosted elsewhere without the express permission from Springer. 